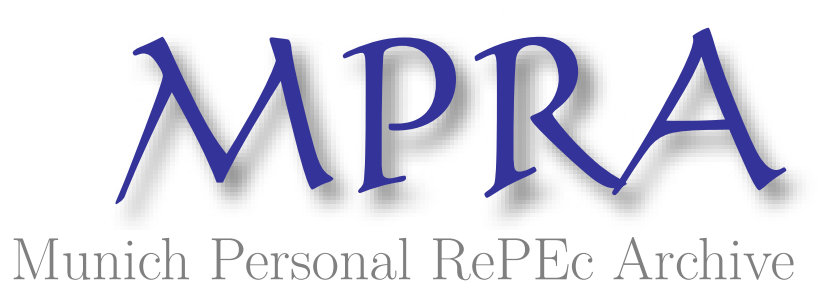

\title{
Corporate Governance, Corporate Finance and Stock Markets in Emerging Countries
}

Singh, Ajit

April 2003

Online at https://mpra.ub.uni-muenchen.de/24302/

MPRA Paper No. 24302, posted 30 Aug 2010 08:31 UTC 


\title{
CORPORATE GOVERNANCE, CORPORATE FINANCE AND \\ STOCK MARKETS IN EMERGING COUNTRIES
}

\author{
Ajit Singh \\ Queens' College, University of Cambridge, CB3 9ET \\ E mail: as14@econ.cam.ac.uk
}

This paper was presented at the 3CL/CBR Conference, Faculty of Law, University of Cambridge, July 2002; at Seoul University, August 2002; and at an UNCTAD workshop in Cairo, 2001. The author is grateful for the comments made at these meetings. Financial assistance for carrying out this project from UNCTAD in Geneva and from the OECD Development Centre in Paris are gratefully acknowledged, as is the assistance provided by the Centre for Business Research, Cambridge. The usual caveat applies. 


\section{Corporate Governance, Corporate Finance and Stock Markets in Emerging} Countries

\section{Introduction. Corporate Governance in Emerging Markets: The National and International Policy Context}

Corporate governance has only recently become the object of serious public concern and policy interest in emerging markets. The Asian crisis of 1997-2000 which devastated some of the world's most successful economies provided a catalyst for such concerns. An analysis of the crisis by some economists and policy makers led to the formulation of an influential thesis which ascribed its deeper causes to structural factors. This thesis, propounded notably by leading U.S. officials (for example Alan Greenspan (1998) and the former Treasury Secretary, Larry Summers (1998) $)^{1}$ suggested that, although certain macro-economic disequilibria may have initiated the Asian economic and financial upheaval, its more fundamental causes lay in the normal day-to-day micro-economic behaviour of economic agents in these countries. According to this theory, the close relationship between governments, business and banks, which characterised these economies, led to crony capitalism and high debtequity ratios for the large favoured firms. It is further argued that poor corporate governance and the lack of competition in product and capital markets resulted in over-investment which in turn led to falling profits and ultimately the crisis.

Although this structuralist thesis is controversial and has been the subject of important criticisms explicitly or implicitly by a number of economists ${ }^{2}$, it did help focus attention on corporate governance and related micro-economic issues in developing countries. Even before the Asian crisis, such refocusing was needed in any case because of important structural changes which had occurred in these countries during the 1980s and the early 1990s. In this period many of them liberalised their financial systems, privatised and deregulated their industries, created and expanded their stock markets and embarked on a whole series of market-oriented reforms. This

\footnotetext{
${ }^{1}$ See also Summers (2000), Frankel (1998), Phelps (1999), Johnson et al. (2000), IMF (1997, 1998), US Council For Economic Advisors (1998, 1999).

${ }^{2}$ See for example Chang (2000), Sakakibara (2001), Singh and Weisse (1999), and Stiglitz (1999).
} 
ascendancy of the private sector needs to be carefully studied from a developmental perspective. (Singh, 1997).

Thus matters of private sector corporate governance became important for emerging countries well before the Asian crisis but were not recognised as a subject for concern. What the crisis did was to make this phenomenon not just one of national but of international significance. The latter was further enhanced by the inclusion of corporate governance in the reform agenda of the New International Financial Architecture (NIFA). The NIFA was instituted by G7 countries in the wake of the Asian crisis to forestall future crises. ${ }^{3}$ The alleged lack of corporate transparency in emerging markets was a particular focus of G7 concern (Camdessus, 1998).

In the context of the current international debate on poverty and development there is also another notable reason for the attention being focused today on corporate governance in emerging markets. This stems from the emphasis in international development policies on governance questions at all levels. Corporate governance is clearly highly relevant to these concerns. As James Wolfensohn (2000:1), President of the World Bank, observed, "The proper governance of companies will become as crucial to the world economy as the proper governing of countries".

This paper focuses on the inter-relationship between corporate governance, corporate finance and the expansion and development of stock markets in emerging countries. It explores both theoretically and empirically the nature of the inter-relationships between these phenomena, as well as their implications for economic policy. It concentrates specifically on the financing of corporate growth, an area of work where the literature has identified important anomalies in relation to corporate governance, and the savings and investment behaviour of economic agents. The paper provides new information and analysis on this subject for the 1990s which leads to further anomalies from the perspective of extant economic theory. It addresses the following main issues:

\footnotetext{
${ }^{3}$ See further Singh, Singh and Weisse (2002).
} 
(1) How do corporate financing patterns theoretically affect corporate governance? How does the latter in turn influence the former?

(2) What is the nature of corporate financing patterns (i.e. how corporations finance their investments and growth) in emerging markets, and how have these evolved during the 1980s and 1990s?

(3) Are there significant differences in financing patterns (a) between emerging and mature markets, and, (b) between emerging markets themselves.

(4) Can economic theory adequately explain the observed inter-country differences in financing patterns as well as the changes in these over time?

(5) How does the stock market affect corporate finance and corporate governance?

In addition the paper also comments very briefly on the work of La Porta and Lopez de Silanes, Shleifer and Vishny (LLSV). These authors in their pioneering contributions have emphasised the role of the legal system in determining the relationship between corporate finance, corporate governance and economic development. (LLSV, 1997, 1998, 1999, 2000). In considering these issues, the paper examines more closely the evolution of the financing of corporate growth and of stock market development in the specific case of the Indian economy in the 1980s and 1990s.

\section{Corporate Financing Patterns in Emerging and Mature Economies: Analytical Considerations}

The paper builds on the author's previous work in this field ${ }^{4}$. Singh and Hamid (1992) and Singh (1995) were among the first large-scale comparative empirical analyses of corporate financing patterns in emerging markets (hereafter referred to as $\mathrm{SH})^{5}$. $\mathrm{SH}$ arrived at surprising and quite unexpected conclusions. This research showed that although there were variations in corporate financing patterns among developing

\footnotetext{
${ }^{4}$ See Singh and Hamid (1992), Singh (1995), Whittington et al. (1997), Singh (1997), Singh and Weisse (1998) and Glen et. al. (2000).

${ }^{5}$ The sample frame of Singh and Hamid (1992) was the fifty largest manufacturing corporations quoted on the stock markets in nine emerging countries, Thailand, South Korea, India, Turkey, Pakistan, Mexico, Jordan, Zimbabwe and Malaysia. Singh (1995) extended the coverage normally to the one hundred largest quoted manufacturing firms in each country and included Brazil in the sample of emerging markets. The latter study, while broadly confirming the conclusions of the earlier research, also qualified them in some important ways. (See further Singh and Weisse (1998) and also below).
} 
countries, in general corporations in the sample countries used more external than internal funds to finance the growth of their net assets. Further, within external sources, the average developing country corporation used new share issues on the stock market to a surprisingly large degree. Even at an elementary level these conclusions are quite contrary to a priori expectations. In view of the low level of development and myriad imperfections of developing country capital markets, one would have expected these corporations to use more internal rather than external finance. For similar reasons, one would not expect immature and small stock markets to be a prominent source of funds for developing country corporations.

An important task of the present paper is to examine the robustness of the SH findings in the light of the evidence for the 1990s. The SH studies analysed the individual corporate accounts of normally the hundred largest manufacturing firms quoted on the stock market and covered the decade of the 1980s. However, before reporting on the robustness exercise and other empirical results, it will be useful to outline more systematically what economic theory has to say on corporate financing patterns in developed and developing countries. During the last fifteen years there has been an avalanche of theoretical literature on the financing of corporate growth and the associated question of the capital structure of firms ${ }^{6}$. The literature points to a number of reasons why financing patterns (based on flow variables) or the capital structure (based on stock variables) may differ between firms. As suggested by Myers (2001), these reasons lead broadly to the following four theories:

(1) The trade-off theory which emphasises the role of taxation.

(2) The pecking order theory which is based on the concept of informational asymmetries.

(3) The agency theory which is based on the separation of ownership and control in modern corporations in mature economies. This theory emphasises the role of corporate financial choices in aligning the interests of shareholders and managers.

\footnotetext{
${ }^{6}$ The seminal review article on the theoretical issues is Harris and Raviv (1991). An authoritative recent contribution is Myers (2001).
} 
(4) Modigliani and Miller's 1958 classic irrelevance theorems which long dominated the field of corporate finance and which asserted that it made no difference how firms financed their growth.

The first three theories represent attempts to reconcile empirical evidence for the real world that financing patterns do seem to matter with the Modigliani and Miller propositions. It is now recognised that the latter only hold in a rarefied neo-classical world in which there is notably no taxation, no provision for bankruptcy, and where there exist stable competitive equilibrium prices. In relation to the differences in financing patterns between emerging and mature markets, which is the main subject of concern in this paper, the most important of these theories are the pecking order theory and the agency theory. The taxation theory (trade-off theory) is more relevant at the empirical level. However, in view of the limited availability of comparative inter-country data on taxation, the latter issues will be considered here only briefly.

\section{II.1 The Pecking Order Theory}

This theory suggests that firms follow a hierarchical pattern in their choice of various sources to finance their investment needs, internal finance (i.e. retained profits) being the first recourse. Should these requirements exceed the available internal finance, firms will then attempt to raise external resources through debt and only as a last resort go to the stock market. The pecking order theory has a ready rationale if one assumes that managers' interests differ from those of shareholders as, for example, in corporations where there is a separation of ownership from control. This would make the controlling managers prefer internal finance over which they have discretion (because of the inability of dispersed shareholders to exercise effective control due to the difficulties of collective action). External finance on the other hand involves scrutiny by the stock market or by banks. However, in a classic contribution Myers and Majluf (1984) showed that, under conditions of imperfect and asymmetric information, even profit maximising managers, that is, those who are trying to maximise shareholders' value, will find that the optimum financial choices are still best represented by the pecking order theory. 


\section{II.2 The Case of Emerging Markets: Pecking Order and Agency Considerations}

The next question is whether at a theoretical level the pecking order theory may be expected to apply also to emerging market corporations. Here we must first note some specificities of emerging countries. These are in part related to the level of overall development of a country and that of its capital markets. At low levels of development where the stock market is either non-existent or exists only in a rudimentary form, and there is a banking system which is also not fully developed, corporations would normally be obliged to rely basically on internal resources and seek external funds rarely, if at all.

In practice, however, the banking system in such economies is likely to be relatively more developed compared with the stock market, even though it would still be far from being perfect. This will mean that firms will be able to raise external funds more from the banks than from the stock market. In other words this would lead to a "pecking order" of the same kind as is suggested for advanced economies but for entirely different reasons. The pecking order in the case of the developing countries would be further reinforced by the fact that business-owning families would like to maintain control of their firms and would therefore prefer debt to equity.

Another characteristic of developing country firms which is relevant, particularly for small and medium size companies, is that of family connections. For such firms, the normal sources of external capital are equity from extended family and friends and loans from the "kerb" market. It is not clear in this regard whether these firms would borrow more or use more equity. Kerb borrowing and informal credit market borrowing tend to be very costly but are often required by small and medium sized firms for short-term working capital. For long term purposes, equity finance from families and friends is likely to be preferred. This implies that the growth of small and medium sized firms would be restricted by financial constraints unless there are government schemes to help them. Governments in many developing countries have established direct financing institutions (DFIs), essentially development banks, to 
provide finance for industrialisation. Typically, however, these institutions have tended to provide funds for large rather than small companies. To the extent that such finance is extended to large firms in the form of loans rather than equity, this would also lead to the consolidation of the pecking order pattern of finance for the large corporations.

Turning to the case of emerging countries at a relatively higher stage of development with better developed banking systems and established stock markets, there will be further reasons to expect the pecking order to prevail. In these semi-industrial countries, although there are likely to exist reasonably sophisticated banking systems, the stock markets, until the 1980s, in most of these countries were quite small and relatively immature (Singh (1997) Mullins (1993)). Specifically, imperfections of the stock market may lead to speculation and arbitrary pricing as well as large volatility in share prices (see further Tirole, 1991 and Singh, 1997). These conditions may discourage risk-averse firms, even those with very good projects, from seeking funds from the stock market or even from obtaining a stock market listing at all. Further, due to the lack of clear-cut bankruptcy laws, or their lax enforcement, large firms in particular many semi-industrial countries, may be expected to resort to bank financing more than to the stock market.

To sum up, the above discussion suggests that, although conditions differ both between emerging countries at various stages of development and between small and large firms, there are good reasons to suggest that the pecking order theory would be applicable at least for large firms. For semi-industrial countries with reasonably welldeveloped banking systems and established equity markets, such as those included in SH studies, large corporations would follow a pecking order pattern of finance not only because of the informational asymmetries emphasized by Myers and Majluf, (1984) but also due to the institutional specificities of emerging markets outlined above. Thus, if there are good reasons to expect a pecking order pattern of finance for corporate growth in developed countries, on account of ownership patterns and agency considerations outlined above, there are even stronger reasons for expecting such a pattern in emerging markets. 


\section{II.3 Research on Law and Finance and Emerging Markets}

Apart from the economic theories of financing corporate growth outlined in II.2 above, LLSV's work referred to earlier suggests that a country's legal system determines its pattern of corporate finance as well as corporate governance and other variables. In their empirical work, the authors distinguish between essentially two ideal type legal systems: the French civil law system and the Anglo-Saxon common law system. It is argued that common law countries would have better protection for minority shareholders, as well as superior corporate governance in other ways (e.g. have regular board meetings and have independent non-executive directors). This would enable corporations in those countries to be able to raise more external finance at cheaper terms than corporations in civil law countries. In this framework the country's legal system is an exogenous variable determined by history and circumstances. In the case of emerging markets, it is suggested that their respective legal systems were often imposed on them by the colonial power which had ruled the country. The LLSV theory is controversial but it has the virtue of having clear-cut testable predictions concerning financing patterns in different emerging as well as mature markets.

\section{Empirical Evidence}

Singh and Hamid's results, referred to earlier, for the corporate financing patterns in ten emerging markets for the 1980s are reported in Table 1. These results are based on individual company accounting data for normally the hundred largest manufacturing firms in each of the sample countries. The results indicate a comprehensive rejection of the pecking order hypothesis for several countries. The average quoted company in the ten emerging markets during the 1980s financed marginally more of its growth of net assets from equity (39.3\%) than from internal sources i.e. retained profits $(38.8 \%){ }^{7}$ Long term debt contributed a little over $20 \%$ to the average sample firm's growth. These were the average figures: in some countries the significance of external finance was considerably greater. Thus, for example, in South Korea nearly $80 \%$ of

\footnotetext{
${ }^{7}$ Net assets refers to the book value of a firm's total assets minus current liabilities.
} 
corporate growth came from external sources (nearly 50\% equity and 30\% long-term debt) and only about $20 \%$ from retained profits.

\section{III.1 Anomalous Behaviour: Emerging Market Corporations and Investors}

The results reported in Table 1 are striking and anomalous for other reasons as well. Not only would it seem that large emerging market corporations finance a great part of their investment needs from external rather than internal funds, they also used the stock market for new issues to a surprisingly large degree, much more so than the corporations in advanced countries. (See Table 2). Tables 2 and 3, which report on the financing of corporate growth in advanced countries for the periods $1970-1989$ and for 1988 - 1997 respectively, suggest that in these countries the stock market provides relatively little fresh capital to the corporate sector. Indeed the contribution of new equity to corporate investment was negative in the U.S. and the U.K. (see Table 2), indicating that more company shares were retired either through take-overs or through share buy-backs than were added by new issues during the relevant period. However, even in Germany and Japan where new equity makes a positive contribution to corporate growth, the proportions are quite small. To find that, compared with these well-organised stock markets in advanced countries, the considerably smaller less developed and immature emerging markets make a sizeable contribution to financing corporate investment certainly calls for an explanation.

This is all the more necessary since developing country stock markets suffer not just from market imperfections (for example, a comparative lack of private informationgathering and monitoring organisations and firms) but also from serious regulatory deficits (including insider trading, lack of protection for minority shareholders). ${ }^{8}$ In addition, as the conceptual analysis of the last section suggested, the share prices on these emerging markets are likely to be much more volatile than in well-developed and mature stock markets. This particular prediction is supported by evidence which indicates that there is indeed a greater share price volatility on emerging markets. ${ }^{9}$

\footnotetext{
${ }^{8}$ Such deficits exist, as we know from the recent experience of the United States, in advanced countries as well but they tend to be much larger in emerging markets with new stock market institutions.

${ }^{9}$ See further El-Erian and Kumar (1994).
} 
One would have expected such volatility to discourage developing country firms from raising capital on the stock market, or even to seek a market listing at all. However, as Table 1 suggests, not only did these companies tap the stock market for large amounts of fresh capital, but further data (not reported in Table 1) indicates that there was a big increase in listings in many emerging markets in the 1980s. Singh (1995, 1997).

Even though India is an extreme case, by the late 1980s the relatively small Indian stock market (by international standards) had become one of the largest in the world in terms of the number of listed companies. ${ }^{10}$ Shleifer and Vishny (1997) point to another anomaly, looked at this time from the perspective of the investing public rather than the corporations. They rightly ask "Who are the buyers of this equity? If they are dispersed shareholders, why are they buying the equity despite the apparent absence of minority protections?"

A still further anomaly arises when the results for advanced countries reported in Tables 2 and 3 are considered. These evidently fully conform to the pecking order theory of financing corporate growth, indicating that firms in these countries overwhelmingly finance their investments from internal sources. When external sources are used debt is much more important than equity. The analytical discussion of Section II suggested that, compared with the advanced country corporations, there are even stronger a priori reasons to expect corporations in emerging markets to follow the pecking order. Yet evidence suggests that the former do so and the latter do not.

\section{III.2 Accounting for the Anomalies}

How does one account for these anomalies? Singh (1995) and in subsequent papers with his colleagues referred to earlier, offered the following analysis for explaining these contrary findings. First he pointed out that a large part of the difference between the results for the emerging and advanced markets reported in Tables 1 and 2

\footnotetext{
${ }^{10}$ See further Singh and Weisse (1998) and Singh (1999)
} 
(and 3) arises from methodological differences between the two types of studies. The following differences are particularly significant:

- The sources of basic data used in the two studies are rather different Table 1 is based on corporate accounting data and Table 2 (as well as Table 3) on the flow-of-funds data. More significantly, an important part of the differences in the empirical results could arise from the fact that in tables 2 and 3 depreciation is included as a major component of internal finance, whereas in Table 1 it is excluded from both the numerator and denominator in the relevant ratios. The purpose of the $\mathrm{SH}$ exercise in Table 1 is to measure the sources of finance for corporate growth of "net assets". It is therefore necessary to focus on the net increase in corporate assets, because depreciation provision for replacement is normally required to merely maintain the stock of assets. Prais (1976) provides the classic discussion of this issue.

- Equally importantly, the results reported in tables 2 and 3, using the flow of funds data, relate to the corporate sector as a whole, rather than to a typical individual firm. In this methodology, intra-corporate sector transactions are usually netted-out and "external finance" means finance from outside the corporate sector. Therefore the question being addressed by the information presented in tables 2 and 3 is: how is "gross physical investment" in the corporate sector as a whole financed, by internal sources (within the corporate sector) and by external sources (from outside the sector, e.g. the financial or the household sector). This is a rather different question than that addressed in Table 1 by the $\mathrm{SH}$ methodology. The latter uses firm-level accounting data to enquire how individual corporations rather than the corporate sector as a whole finance the growth of their net assets, net of depreciation.

- The differences between the two methodologies is best illustrated by considering the case of take-overs. If a corporation, for example, within the non-financial sector takes over another corporation within that sector, 
and pays for the acquisition with its own shares, this is regarded by $\mathrm{SH}$ as a new investment by the acquiring firm, financed through the issue of fresh equity. The rationale for this approach is that, from the point of view of the individual firm, growth by acquisition is an alternative to the creation of new productive capacity. From the standpoint of the corporate sector as a whole, however, there is no increase at all either in "physical investment" or in the shares issued. Thus in the methodology used in tables 2 and 3 such intra-sectoral transactions are netted out.

Singh (1995) provided indirect evidence to suggest that the differences between the financing pattern of advanced and developing country corporations are very much smaller when the same methodology is used for both groups of firms. ${ }^{11}$ The next section provides direct evidence on this point.

Quite apart from the methodological differences noted above some of the anomalous results could, however, also arise from the possible measurement biases in $\mathrm{SH}$ studies $^{12}$. The latter were fully acknowledged in Singh (1995) and examined more closely in Whittington, Saporta and Singh (1997). Two of the possible biases are particularly relevant: a) the use of the historical cost method of accounting in periods of high inflation; and b) in the absence of the necessary data, a bias is introduced by using an indirect method to assess the contribution of the equity variables in $\mathrm{SH}$ research.

As is well known, inflation could distort the historic cost accounts to give a misleading picture of corporate performance and financing patterns. For example, $a$ priori it could either understate or overstate corporate profits (and consequently the amount of retained profits) unless an appropriate adjustment has been made. With respect to (b), in SH studies, in the absence of readily available data, the variable "equity finance" was measured indirectly from the accounting identity which equates growth of net assets with the sum of internal and external finance respectively. Further in these studies the growth of long-term liabilities was proxied by growth of

\footnotetext{
${ }^{11}$ This qualified an important conclusion of Singh and Hamid (1992). See further Singh (1995), p.21 and also Singh and Weisse (1998).

${ }^{12}$ See also Cobham and Subramaniam (1998) and Samuel (1996).
} 
long-term debt and the growth of internal finance by retained profits. Whittington et al (1997) in their analysis of these biases indicate that, although significant in some cases they do not vitiate the surprising central empirical findings of $\mathrm{SH}$ studies, that is, that large developing country corporations use more external than internal finance and employ equity finance to a rather large degree.

Singh (1995) provided an economic explanation for these anomalous findings, essentially in terms of conjunctural factors which were specific to the 1980s and were expected eventually to peter out. He ascribed the relatively high use of external finance by developing country corporations to their fast growth rates. He then concentrated on the question of the large reliance of these corporations on equity finance. He attributed this phenomenon to financial liberalisation, de-regulation and privatisation which many developing countries implemented in the 1980's. Specifically he called attention to the following factors:

a) The very fast development of stock markets which was stimulated and encouraged by governments through regulatory changes and other measures. In many emerging countries an important purpose of these policies was to facilitate privatisation.

b) Equity financing was also encouraged in a number of countries by tax incentives.

c) External and internal financial liberalisation which often lead both to a stock market boom and to higher real interest rates; the former lowered the cost of equity capital whilst the latter increased the cost of debt finance. These changes in relative prices, which were quite dramatic, are likely to have contributed to the observed greater use of equity compared with debt by large corporations in a number of these economies during this period. ${ }^{13}$

\section{Empirical Evidence for the 1990s}

\footnotetext{
${ }^{13}$ These issues are of course more complex; for a detailed discussion see Singh (1995).
} 
This section provides a unified analysis of corporate financing patterns in emerging and advanced economies during the 1990s using the same methodology and the same data source - the World Scope Data Bank. This data bank is more comprehensive than the accounting information used in SH studies. Apart from its intrinsic interest in describing the corporate financing patterns for the 1990s, the results of this analysis also have a bearing on the issue of measurement biases outlined above.

Tables 4 - 7 analyse corporate financing patterns in four emerging markets (India, Malaysia, Thailand and Korea), and two mature economies (the U.S. and the U.K.), during the period 1992 to 1996 using the same methodology, essentially that of SH studies in Table 1 (but see discussion later in this section). The results reported in Table 4 provide fascinating information which may be summarised as follows:

i) The differences between the corporate financing patterns for mature and for emerging economies are much less marked, when the same methodology and the same information, that is, the corporate accounting data, are used to examine financing patterns.

ii) The pecking order pattern of finance is not supported either for emerging markets or for mature economies ${ }^{14}$.

iii) There are marked differences between the two mature economies. In the U.K., internal finance provides only $12.6 \%$ of the total sources of finance. Of the external finance $(87.3 \%)$ more than one third is provided by equity issues, which is very considerably more than in the U.S. (8.4\%). It is also notable that short term debt, including trade credit, comprises $48.9 \%$ of the total financing for the U.K. firms and only $28.1 \%$ for the U.S. firms. Indeed the pattern of financing for the U.K. companies seems similar to those for developing countries.

\footnotetext{
${ }^{14}$ In the case of the U.K., the rejection of the hypothesis is unequivocal. For the US the results are more marginal especially if the information in Table 5 is also taken into account. The latter which excludes short term external financing indicates that marginally more finance came from internal
} 
iv) In the U.S., however, internal finance accounted for $31.8 \%$ and long term debt finance $30.6 \%$, marginally less than internal finance. However, long term external finance as a whole greatly exceeded internal finance.

v) The results for developing countries indicate their continuing heavy reliance on external sources (ranging from $76 \%$ for India to $94 \%$ for Korea). However, the composition of external finance is different from that of the 1980s: there is greater use of debt finance, particularly short term debt, than that of equity issues.

It is useful to note that although it employs the same type of methodology as that in Table 1, the table 4 analysis is more comprehensive. The results are also less subject to some of the possible measurement biases, which, as noted earlier, could affect the analysis presented in Table 1. Differences between the analyses of Tables 1 and 4 may be summarised as follows:

- Table 4, using the World Scope data set, measures the contribution of equity finance directly, as this data base provides that information, whereas in table 1 $\mathrm{SH}$ used an indirect residual method for estimating this variable because of data limitations;

- The "external sources of finance" in table 4 includes all types of finance, long term as well as short term, including trade credit and short-term debt, whereas table 1 did not include short term finance, that is bank loans of a duration of up to one year. As subsequent events revealed this was not a good methodology: long term debt is not an adequate reflection of the normal indebtness of developing country corporations. This is because the latter typically use large amounts of short term debt for long term investment purposes. Such debt is normally rolled over, turning it into the functional

sources than from long term debt. However long term external finance as a whole greatly exceeded internal finance. 
equivalent of long term debt. Creditors may, however, refuse to roll over these debts in times of crisis, as exemplified by the Asian crisis of 1997-1998;

- Table 4 includes a separate category for revaluation reserves, minority interests, preferred shares and non-equity reserves. This category is usually quite small for most countries.

However, Table 5 provides the same information as table 4 except that it only examines long term sources of finance. This makes it more comparable to the data reported in table 1 except for the differences already noted in the first and third bullet points above.

Taking Tables 4 and 5 together, the results raise three substantive economic issues in the context of the previous discussion:

1. In the case of the U.S. and the U.K. corporations, especially the latter, the results do not provide much support for the pecking order theory. However, economic analysis as well as evidence in Tables 2 and 3 indicate otherwise. Why should this be so?

2. Why are the results reported for the U.S. so different from those for the U.K. in other respects, particularly as these countries have similar legal and financial institutions and well-developed stock markets?

3. Are the apparent changes in equity financing in the 1990s compared with the 1980s in emerging markets "genuine" or simply a consequence of the measurement biases in the 1980s benchmark figures?

The answer to the first question is implicit in the methodological discussion of the last section. Different methodologies are being used in the two sets of tables and the main question therefore is, which method is more appropriate? There are good reasons to suggest that the SH type methodology used in Tables 4 and 5 is more suitable, essentially because it is considering the issue of financing corporate growth from the 
perspective of an individual firm rather than that of the corporate sector as a whole. The theoretical discussion of the pecking order hypothesis in Section II, it will be recalled, is conducted in terms of the behaviour of the individual firm rather than that of the whole of the corporate sector.

With respect to the second question, the differences in the sources of finance for corporate growth in the U.S. and the U.K. appear to arise mainly from the fact that the World Scope data set for the . relates to the top 200 or so corporations, whereas for the U.K., it covers 700 corporations. (In this whole exercise, all available relevant information from the World Scope data set for each country has been used.) It is therefore likely that the main reason for the differences between the U.S. and the U.K. arise from the fact that the financing patterns of large corporations are different from those of small corporations. This hypothesis will be examined in subsequent work.

Turning to the third question, since the World Scope data only starts in 1990, this question cannot be answered directly. However, the data set does provide information for an indirect test of the effects of possible measurement errors in the treatment of the equity financing variable in the benchmark SH studies for the 1980s. Tables 6 and 7 use World Scope Data for the 1990s for a sample of four countries (India, Korea, Thailand and Malaysia) to analyse financing patterns using the direct method for measuring the contribution of equity finance (Table 6) and the SH residual method in Table $7 .{ }^{15}$ A comparison of Tables 6 and 7 indicates that for both India and Korea, the residual method slightly underestimates the contribution of equity finance, while in the case of Malaysia it considerably over-estimates it. Both methods give the same results for Thailand. Thus, in three out of four countries, this analysis suggests that the SH method is unlikely to have over-stated the contribution of equity finance. The balance of evidence (including that of Whittington et al 1997 discussed earlier) therefore suggests that the observed changes in corporate financing patterns from the 1980 s to the 1990 s for these countries are likely to be genuine rather than simply reflecting measurement biases of the earlier period.

\footnotetext{
${ }^{15}$ This exercise for the 1990s is a much simpler version of the analysis of the measurement biases on the basis of the 1980s data carried out by Whittington et al 1997.
} 
Finally, the relatively high use of equity financing by emerging market corporations in the 1980s and into the 1990s is also confirmed by the data reported in Table 8 . This information comes from a completely different data set which provides aggregate levels of new equity and debt issues relative to various macro-economic benchmark variables for a group of developing and developed countries. The data reported in table 8 gives new equity issues as a proportion of total stock market capitalisation. The table shows higher levels of equity issues for a number of emerging markets compared with those for advanced countries. The Korean case with extremely high levels of new equity issues is clearly an outlier.

It may be useful at this stage to sum up the main conclusions of the above analysis of corporate financing patterns in emerging and mature markets during the 1980s and 1990s. The main points are as follows.

1. Contrary to a priori expectations and theoretical analysis, the observed corporate financing patterns in several leading emerging markets comprehensively reject the pecking order theory. The conceptual discussion in Section II concluded that, while good reasons exist to expect a pecking order for firms in mature markets, the reasons for expecting such a pattern for emerging market firms are stronger still. Yet the results for the 1980s and 1990s are quite unequivocal: emerging market firms use far more external rather than internal finance, and within external finance employ equity finance to a surprisingly large degree. Thus the analysis shows that the phenomenon of high reliance on external financing did not peter out but continued in the period studied in the 1990s, though in a less attenuated form.

2. Evidence suggests that these results are unlikely to be due to possible measurement biases arising from the inadequacies of the available data for the 1980s. The more comprehensive data for the 1990s confirms these conclusions.

3. The large observed differences between the financing patterns of emerging and mature markets arise mainly from the different methodologies which have 
been used for examining these issues. When the same methodology is used to study financing patterns in both groups of countries, the financing patterns are seen to be much closer. However, the theoretical anomaly still remains and is indeed compounded in the data for the 1990s.

4. When the SH methodology is used for studying corporate financing patterns in advanced economies, the widely held belief that these corporations implement a pecking order may not be valid for all countries in all periods. At a minimum, the analysis of this paper suggests that evidence for the pecking order is not robust. With a different methodology which, it is argued here, is conceptually more suitable, the results change quite considerably. The pecking order pattern in advanced economies is most evident when flow of funds data is used and the question of financing is considered from the perspective of the corporate sector as a whole rather than that of the individual firm. Since the theoretical foundation of the pecking order theory is the individual firm, rather than the corporate sector as a whole, the $\mathrm{SH}$ methodology embodying this perspective is therefore more appropriate.

5. The foregoing four conclusions outlined in paragraphs 1-4 above are, however, based on limited data. The data for the 1990s, for example, covers a limited number of firms for two advanced countries and four developing countries. Until these findings are tested for a larger body of data, these conclusions must remain provisional. However, the fact that the anomalous results for the 1980s for developing country corporations continued to be valid in the 1990s does suggest that this phenomenon requires serious attention.

\section{Corporate Finance, the Stock Market and Corporate Governance ${ }^{16}$}

The previous section has indicated that there is considerable evidence from different kinds of data, both at the aggregate and at the micro-economic levels, that the large emerging market firms have raised substantial amounts of funds on the stock market

\footnotetext{
${ }^{16}$ The analysis of this section is based on Singh, Singh and Weisse (2002) and Singh (1999)
} 
during the 1980s and 1990s. In proportional terms during this period, equity financing of large firms from many emerging markets was greater than that of firms from advanced economies.

In view of the large recourse to equity financing by developing country firms, stock markets might be expected to significantly affect corporate behaviour (for example, corporate policies with respect to the payment of dividends), as well as corporate governance (for example, the extent to which managers run the corporation in the interests of the shareholders or themselves). The stock market can affect corporate governance and behaviour directly as well as indirectly. The direct effect is through the stock market's own rules and regulations, for example requirements for listing and raising new issues. In these areas, emerging stock markets usually display considerable deficits in comparison with advanced country markets. Listing and disclosure requirements, for example, in advanced countries' stock markets tend to be more stringent and more actively enforced than those in developing country markets.

\section{V.1 The Pricing Mechanism}

However, more significantly, the stock market can influence corporate governance indirectly through its allocative and disciplinary mechanisms. Each of these channels is important.

The market performs its allocative tasks basically by its pricing of corporate securities. In traditional textbook treatments of the subject, the liquid secondary equity market results in a better allocation of funds that results in more efficient and dynamic firms obtaining capital at lower cost. Similarly, less efficient firms or firms in less dynamic industries face a higher cost of equity capital. The result is the movement of funds to more efficient, productive firms that results in higher degrees of technological progress and economic growth.

However, a more critical literature originating in the work of John Maynard Keynes has pointed out that the pricing process may not be as efficient as the textbooks suggest, but may instead be dominated by speculation. James Tobin (1984) has 
distinguished two concepts of share price efficiency on the stock market: information arbitrage efficiency (in the sense that all currently available information is rapidly incorporated into the share price) and fundamental valuation efficiency (share prices accurately reflect the future discounted earnings of the corporation). While real world stock market prices may reflect the former, the critical school maintains that there are strong reasons to doubt that it always attains the latter, more important, criterion of efficiency. The reasons for this are found in the psychology of stock market participants. ${ }^{17}$ As Keynes pointed out in his famous description of the beauty contest in the General Theory, often the art of the successful investor does not consist in appreciating fundamental values of corporations, but rather in guessing at the likely movements of other stock market participants. Such a process leads to herding, myopia and fads that can lead stock market values to diverge significantly from underlying values (for a current example, note the rise and fall of technology shares on international stock markets). The volatility associated with this process further reduces the capacity of share prices to transmit efficient signals to market participants.

Experience from advanced countries suggests that the stock market may also encourage managers to pursue short-term profits at the expense of long-term investment since firms are obliged to meet quarterly or half-yearly earnings per share targets determined by market expectations. Any serious fall in such short-term performance will quickly be reflected in a lower share price making the firm vulnerable to take-over. In the late 1980s and early 1990s, numerous analysts in the United States ascribed that country's relatively poor comparative performance vis-àvis competitors with bank-based financial systems such as Japan and Germany to the short-termist demands of Wall Street resulting in lower investment in technological upgrading and new capacity. ${ }^{18}$ In a closely related but more general sense, the dominance of stock markets may result in the rules of the game being constructed in such a way that companies can rise or fall depending on their ability to engage in financial engineering rather than in developing new products or processes. This is

\footnotetext{
${ }^{17}$ Benjamin Graham, in his classic work on security analysis noted that "The stock market is a voting machine rather than a weighing machine." (Graham, 1934, p.452).

${ }^{18}$ See collection of studies in Porter 1992. See also Singh (2000).
} 
often reflected within the firm itself in the dominance of managers trained in finance over those who come from other backgrounds such as engineering or marketing.

Thus, the benefits of having large corporations dependent on a highly liquid equity market are far from being unambiguous, particularly from the perspective of good corporate governance (see further Bhide, 1994).

\section{V.2 Corporate Governance and Take-overs}

An efficient market for corporate control is thought to be the evolutionary endpoint of stock market development in that it obliges all managers to maximise shareholders' wealth. The ability of an outside group of investors to acquire a corporation, often through a hostile bid, is the hallmark of the stock market-dominated U.S. and U.K. corporate and financial systems. The textbook interpretation of take-overs is that they improve efficiency by transferring corporate assets to those who can manage them more productively. Consequently, more effective managers emerge who can raise the firm's profitability and share price. Even if current managers are not replaced, an active market for corporate control presents a credible threat that inefficient managers will be replaced and thus ensures that the incumbent management actively seeks to maximize shareholder value and thereby raises corporate performance. Even if quoted firms were not directly susceptible to changes in share prices because they finance themselves almost exclusively from internal finance (as the pecking order theory in its strong form implies) the managers can still be disciplined by the market for corporate control. Furthermore, the textbooks suggest that, even if all firms are on the efficiency frontier, the amalgamation of some through the act of take-overs may lead to a better social allocation of resources via synergy.

However, a critical school has developed a multifaceted critique that has increasingly questioned the above textbook version of the market for corporate control. First, a number of analysts in the critical school have pointed out that in the real world the market for corporate control, even in advanced economies, has an inherent flaw in its operation: it is far easier for a large firm to take over a small one than the other way around (Singh, 1971, 1975, 1992, 2000). In principle, it is possible that a small efficient firm may take over a larger and less efficient company (and to a degree this 
occurred in the U.S. take-over wave of the 1980s through "junk bonds"), its incidence was very small (Hughes, 1991).

This consideration is particularly important for developing countries like India where there are large, potentially predatory conglomerate groups (Singh, 1995, 1998). These could take over smaller, more efficient firms and thereby reduce potential competition to the detriment of the real economy. In a take-over battle it is the absolute firepower (absolute size) that counts rather than the relative efficiency. Therefore, the development of an active market for corporate control may encourage managers to "empire-build" not only to increase their monopoly power but also to progressively shield themselves from take-over by becoming larger (see further Singh, 1975, 1992).

Secondly, the efficient operation of the take-over mechanism requires that enormous amounts of information are widely available. Specifically, market participants require information on the profitability of corporations under their existing management and what their prospective profitability would be under an alternative management if it were taken over. It has been noted that such information is not easily available even in advanced countries and this informational deficit is likely to be greater in developing countries.

Thirdly, take-overs are a very expensive way of changing management (Peacock and Bannock, 1991). There are huge transactions costs associated with take-overs in countries like the U.S. and U.K. which hinder the efficiency of the take-over mechanism. Given the lower income levels in the developing countries, these costs are likely to be proportionally heavier in these countries. It should also be borne in mind that many countries with a long-term record of economic success such as Japan, Germany and France have not had an active market for corporate control and have thus avoided these costs, while still maintaining systems for disciplining managers. Furthermore, there is no evidence that corporate governance necessarily improves after take-overs. This is for the simple reason that all take-overs are not disciplinary; in many of them the acquiring firm is motivated by empire-building considerations or even by asset-stripping. 
Fourthly, there is theoretical work (see for example Stein, 1989) which suggests that, even if managers wish to maximise shareholder wealth, it would pay them to be myopic in a world of take-overs and signal-jamming. Thus, take-overs could exacerbate the already present tendencies towards short-termism in a stock marketbased system.

Fifthly, it has been argued that take-overs can be used as a device to avoid honouring implicit contracts developed between workers and the former management (Shleifer and Summers, 1988). This point may be even stronger than that suggested by these authors, in that even the threat of disciplining take-overs by corporations maximising shareholder value may in any case undermine implicit agreements between current management and workers. This abandonment of implicit contracts can be argued to be socially harmful in that it discourages the accumulation of firm-specific human capital by workers. The absence of strong worker-protection laws in many developing countries means that such considerations may be significant.

These critiques of the market for corporate control have been based on the experience of advanced countries. There is every reason to believe, however, that they are likely to be even more relevant to potential take-over markets in developing countries. However, the take-over market in developing countries remains rudimentary because of the fact, noted earlier, that shareholding is not widely dispersed and standards of disclosure are not conducive to take-overs. It is therefore not surprising that hostile take-overs are rare in developing countries: for example, in the last decade in India there have only been five or six such take-over attempts, not all of which were successful. However, this situation may change if large international MNCs are allowed to engage in take-overs in developing countries. Domestic firms, with their limited funds and relatively restricted access to international capital markets, would not be able to either compete with or to resist the MNCs. (See further Singh, 2002). 
VI Stock market Development and Corporate Finance in India and the LLSV Thesis

This section reports more fully on the expansion of the stock market and the financing of corporate growth in India during the last two decades. This is of interest in its own right as well as for being the experience of a classically 'repressed' economy in the McKinnon and Shaw sense, which decided to liberalise its financial sector in the 1980s and 90s. However, the Indian case is particularly useful to study with respect to the LLSV propositions on legal origins and corporate finance. Among emerging markets India is pre-eminently a common law country with a well developed system of laws and justice, litigious middle/upper classes where contracts are enforced through the legal machinery although, to be sure, there is a common complaint that the wheels of justice turn too slowly. Following the U.S., the country has a written constitution that combines the British legal tradition with the U.S. system of justice and Indian judges have shown themselves willing to take on class action suits as well as public interest litigation to curb the excesses of the executive branch of the government. India should therefore be a good laboratory for examining some of the LLSV propositions.

The main relevant facts about the evolution of stock markets and the financing of corporate growth in India may be summarised as follows (Singh and Weisse 1998, Singh 1998):

a) While the Indian stock market was founded more than a century ago, from the time of independence in 1947 until the 1980s it had remained a sleepy backwater in the Indian financial system, with little scope for expansion in a regime dominated by state-directed credit. In 1980, the stock market capitalization ratio was only $5 \%$ of GDP. As a result of liberalization measures initiated in the 1980s, the ratio had risen to $13 \%$ by 1990 . After the major change in government policy and the acceleration of the pace of liberalization in 1991 (see further, below), stock market growth was explosive. By the end of 1993, total market capitalization had reached $40 \%$. 
b) The number of shareholders and investors in mutual funds rose from 2 to 40 million between 1980 and 1993. In absolute size, this made the Indian investor population the second largest in the world, second only to the U.S. which had about 51 million investors at the time.

c) In terms of the number of companies listed on the stock markets, there was again a very fast expansion in the 1980s and 1990s. As seen earlier the Indian stock market by the end of 1995 was the largest in the world, with nearly 8,000 listed companies.

d) On the biggest Indian stock exchange at Bombay, the daily turnover of shares increased almost 30-fold during the 1980s and early 1990s - from 0.13 billion rupees in 1980-81 to 3.7 billion rupees in 1993-94. The average daily trading volume on the Bombay stock market in the early 1990s was about the same as that in London about 45,000 trades a day. At the peak of stock market activity, trading occurred at double that rate. Put through in a short period of 2 hours, these deals on the Bombay stock exchange were reported to have the highest density of transactions in the world, behind only that of the Taiwan stock exchange (Mayya, 1995).

e) During the 1980s and the first half of the 1990s, Indian corporations raised large amounts of capital on a very active primary market for new issues to finance their growth. In 1980, Rs $929 \mathrm{~m}$. were raised through corporate securities issuance (Balasubramanian, 1993). This figure had risen to Rs 2.5 bn by 1985, to a huge Rs 123 bn by 1990, and by 1993-4, it reached Rs 225 bn, i.e. a 250 -fold increase since 1980. By contrast the general price level in the economy rose less than fourfold during this period. Another indicator of an extremely active primary market was that in 1994-5 nearly 1700 companies raised equity capital (either through direct offerings to the public or through rights issues); of these, 369 were new companies (RBI, 1995).

f) The Singh and Hamid (1992) and Singh (1995) studies referred to earlier indicated that for India the average corporation, during the 1980s, financed about 40 per cent of its growth of 'net assets' (the long-term capital employed in the firm) from internal 
sources (i.e. retained profits) and 60 percent from external sources. Of the latter, nearly a third came from equity issues and two-thirds from long-term debt.

In the 1990s, unlike the case of the other sample emerging countries considered earlier, there was a modest increase in equity financing in India in the first half of the decade, compared with the benchmark figure for the 1980s. This difference between India and the other emerging markets can be attributed to the fact that financial liberalisation and related measures were implemented at an accelerated pace in India only in the early 1990s following the balance of payments crisis in 1991. These reforms produced among other things a stock market boom, which reached its peak in 1995. This greatly lowered the cost of equity finance relative to that of debt and consequently several hundred Indian companies, existing as well as new ones, resorted to the stock market to raise finance. However, by the late 1990s, with the fall in share prices there was a sharp reduction in equity financing. ${ }^{19}$ Thus the increase in equity financing for India in the first half of the 1990s was quite in accord with the SH hypotheses as is the subsequent fall recorded in other studies (see Pal (2001)).

g) Although Indian stock market growth during the 1980s and until the mid-90s has been impressive, it is important to note that so has it been in several other leading emerging markets. In Taiwan, market capitalization as a proportion of GDP rose from 11 per cent in 1981 to 74 per cent in 1991. Similarly, between 1983 and 1993, the Chilean ratio rose from 13.2 to 78 per cent and the Thai from 3.8 to 55.8 per cent. To put these figures in an historical perspective, Mullins (1993) notes that it probably took the U.S. stock market 85 years (1810-95) to achieve a broadly similar increase in capitalization ratio, from 7 to 71 per cent.

h) The Indian economic reforms of the 1990s have not only been associated with the vast expansion of stock market activity, but also with important steps to improve the functioning of the markets, to make them more transparent, and less subject to insider dealing and fraud. Although the regulatory authority, the Securities and Exchange Board of India (SEBI), has apparently made some progress in a number of these

\footnotetext{
${ }^{19}$ The World Scope data set analysed in this paper covers only the period 1992 - 1996. For a study of the evolution of financing patterns in the following years, see Pal (2001).
} 
areas, it will be a long time before the Indian stock market loses its justly deserved reputation of being a "snake pit" to use Joshi and Little's expressive phrase. Indeed, notwithstanding SEBI's valiant efforts, the Indian press continues to regale stories of fresh stock market scams.

Apart from their other implications, these facts raise some important issues for the LLSV thesis. What the Indian case suggests is that there can be very quick but far-reaching changes in corporate finance and stock market development such as those which occurred in the country during the 1980s and in the early 1990s. There was, however, no fundamental change in the basic legal framework or in the principles of company law, or for that matter in the degree of enforcement which preceded or accompanied these developments. The government changed economic policy and direction in the 1980s and the long dormant stock market burst into life. It turned into an important source for financing corporate growth as well as providing a vehicle for the savings of households. A similar mixture of changes in government policy and external economic environment occurred in a number of other emerging markets as well during the 1980s, leading to a very fast expansion of stock market activity: this happened both in civil law and in common law countries such as India. These enormous changes in economic policy and financial systems in the various emerging countries occurred in very different economic systems, cultural environments, and legal systems. There is clearly a complex interrelationship between these factors and there is no reason to single out the legal system as the dominant one.

\section{Summary and Conclusion}

This paper has examined the relationship between corporate finance and corporate governance, as well as the important role of the stock market in linking the two phenomena. It has provided new information on corporate financing patterns in emerging markets during the 1990s and these have been systematically compared with the patterns observed in the benchmark SH studies for the 1980s. The paper has also briefly commented on the LLSV legal origin approach to corporate finance, governance and behaviour. 
The central conclusion of this analysis is that the anomalous financing behaviour of emerging market corporations observed in the 1980s has broadly continued into the 1990s; it has not petered out although it has been attenuated to some degree. These corporations still rely overwhelmingly on external sources rather than retained profits to finance the growth of their net assets. The relative contribution of equity versus debt to total external financing changes over time and between countries in response to economic conditions. The results indicate that when the same methodology is used for comparing financing patterns between advanced and emerging markets, the differences between the two are much less sharp. The differences as well as the similarities in the financing patterns of the two groups nevertheless remain theoretically anomalous in a number of dimensions.

Whether the large role of the stock market in financing corporate growth in emerging countries would lead to positive or negative changes in corporate governance and economic efficiency depends on (a) the efficiency of the pricing mechanism and (b) the take-over mechanisms on the real world stock markets. This paper has argued that there is a wealth of evidence that the former is often dominated by speculation, herding and fads that undermine its capacity to efficiently direct the allocation of resources. It has also been suggested that the take-over mechanism is inherently flawed and an expensive method of changing corporate governance. Furthermore, it was pointed out that the inadequacies and perverse incentives in both the pricing process and the takeover mechanism are likely to be exacerbated in developing countries.

In relation to the LLSV studies, the paper suggests that the legal origin approach is unable to account for the huge changes in corporate financing patterns and stock market development, which took place within emerging markets such as India in the 1980s and 1990s. Thus, even if we accepted that legal origin may explain some of the crosssectional variation between developing countries, it is not helpful in explaining the much more important structural changes that have taken place in these countries over the last two decades. None of this is, however, to detract from the immense contribution LLSV have made to research on emerging markets in these areas. 
In conclusion, it may be useful to draw attention to the recent examination by Gugler et al (2002) of the financing anomalies highlighted in this paper. The authors note that Singh's finding of a greater popularity for external financing for developing country corporations seems to contradict various hypotheses of why hierarchy of finance exist. Gugler et al provide an ingenious resolution to these as well as some other financing paradoxes in the literature, in terms of corporate governance institutions. Their empirical analysis indicates that the differences in corporate governance structure helps explain both differences in the sources of finance for investment across countries and differences in the returns on these investments. They argue that corporate governance institutions are weaker in developing than in developed countries which permits owner-managers in developing country corporations to issue equity to finance low return investments. Thus, in this analysis, corporate governance is the independent variable that influences corporate financing patterns which is the dependent variable. This is an important and thoughtful approach which greatly enriches the nascent literature on corporate governance in emerging markets.

In view of the domestic and international policy significance of corporate governance issues for emerging countries outlined in the Introduction, it is essential that these issues be investigated scientifically and dispassionately so as to provide these countries with a solid analytical and empirical basis for policy. With the pioneering contributions of LLSV, Gugler et al. and others reviewed in this paper, this process seems to have begun in earnest. In that sense this paper represents the beginning of an exciting research programme rather than the end. 
Table 1. The financing of corporate growth in ten emerging markets during the 1980s

\begin{tabular}{|l|l|l|l|}
\hline Country & Internal finance & $\begin{array}{l}\text { External finance } \\
(\text { equity })\end{array}$ & $\begin{array}{l}\text { External finance } \\
\text { LD }\end{array}$ \\
\hline Brazil & 56.4 & 36.0 & 7.7 \\
\hline India & 40.5 & 19.6 & 39.9 \\
\hline Jordan & 66.3 & 22.1 & 11.6 \\
\hline Malaysia & 35.6 & 46.6 & 17.8 \\
\hline Mexico & 24.4 & 66.6 & 9.0 \\
\hline Pakistan & 74.0 & 1.7 & 24.3 \\
\hline Republic of Korea & 19.5 & 49.6 & 30.9 \\
\hline Thailand & 27.7 & $\mathrm{NA}$ & $\mathrm{NA}$ \\
\hline Turkey & 15.3 & 65.1 & 19.6 \\
\hline Zimbabwe & 58.0 & 38.8 & 3.2 \\
\hline All & 38.8 & 39.3 & 20.8 \\
\hline $\mathrm{F}^{1}$ & $20.0 *$ & $31.4 *$ & $21.2^{*}$ \\
\hline $\mathrm{F}^{2}$ & $16.69^{*}$ & $18.93^{*}$ & $6.38^{*}$ \\
\hline
\end{tabular}

Note:

1. F-statistic for comparison of means across countries. '*' implies rejection of the null hypothesis of the equality of means

2. Bartlett-Box F-statistic for variance across countries. '*' implies rejection of the null hypothesis of equality of variance.

Source: Singh 1995. 
Table 2: Net sources of finance for Germany, Japan, U.K. and U.S., 1970 - 1989 (percentages)

\begin{tabular}{|l|l|l|l|l|}
\hline & Germany & Japan & U.K. & U.S. \\
\hline Internal & 80.6 & 69.3 & 97.3 & 91.3 \\
\hline Bank finance & 11.0 & 30.5 & 19.5 & 16.6 \\
\hline Bonds & -0.6 & 4.7 & 3.5 & 17.1 \\
\hline New equity & 0.9 & 3.7 & -10.4 & -8.8 \\
\hline Trade Credit & -1.9 & -8.1 & -1.4 & -3.7 \\
\hline Capital transfers & 8.5 & - & 2.5 & - \\
\hline Other & 1.5 & -0.1 & -2.9 & -3.8 \\
\hline Statistical adj. & 0.0 & 0.0 & -8.0 & -8.7 \\
\hline
\end{tabular}

Source: Corbett and Jenkinson (1994) 
Table 3: Sources and uses of funds in non-financial corporations expressed as percentage of each year's total investment, United States, 1988-1997

\begin{tabular}{|c|c|c|c|c|c|c|c|c|c|c|}
\hline & 1988 & 1989 & 1990 & 1991 & 1992 & 1993 & 1994 & 1995 & 1996 & 1997 \\
\hline \multicolumn{11}{|l|}{ Uses } \\
\hline $\begin{array}{l}1 . \quad \text { Capital } \\
\text { expenditures }\end{array}$ & 74 & 87 & 87 & 98 & 73 & 81 & 80 & 77 & 81 & 83 \\
\hline $\begin{array}{l}\text { 1. Investment in } \\
\text { net working } \\
\text { capital and } \\
\text { 2. } \text { other uses }^{\mathrm{a}}\end{array}$ & 26 & 13 & 13 & 2 & 27 & 19 & 20 & 23 & 19 & 17 \\
\hline 3. Total investment & 100 & 100 & 100 & 100 & 100 & 100 & 100 & 100 & 100 & 100 \\
\hline \multicolumn{11}{|l|}{ Sources } \\
\hline $\begin{array}{l}\text { 4. Internally } \\
\text { generated cash }^{\mathrm{b}}\end{array}$ & 81 & 87 & 90 & 112 & 88 & 88 & 86 & 78 & 89 & 85 \\
\hline $\begin{array}{l}\text { 5. Financial deficit } \\
(3-4) ; \quad \text { equals } \\
\text { required external } \\
\text { financing }\end{array}$ & 19 & 13 & 10 & -12 & 12 & 12 & 14 & 22 & 11 & 15 \\
\hline $\begin{array}{l}\text { Financial deficit } \\
\text { covered by }^{c}\end{array}$ & & & & & & & & & & \\
\hline
\end{tabular}

Source: Brealy and Myers (1999)

${ }^{a}$ changes in short term borrowing are shown under net increase in debt. "Other uses" are net of any increase in miscellaneous liabilities and any statistical discrepancy.

${ }^{\mathrm{b}}$ net income plus depreciation less cash dividends paid to stock holders. 


\begin{tabular}{|l|l|l|l|l|l|l|l|l|l|l|}
\hline 6. Net stock issues & -26 & -27 & -14 & 3 & 6 & 4 & -7 & -8 & -9 & -14 \\
\hline $\begin{array}{l}\text { 7. Net increase in } \\
\text { debt }\end{array}$ & 45 & 40 & 24 & -14 & 7 & 8 & 21 & 30 & 20 & 30 \\
\hline
\end{tabular}

${ }^{\mathrm{c}}$ columns may not add up due to rounding 


\section{$\underline{\text { Table } 4}$}

\section{Balanced sample: Sources of financing of growth of Total Assets, $1992-1996$}

Weighted averages are calculated as the sum (over companies) of each source of finance over the sample period, 1992-96, divide by the sum of the growth in total assets over this period. Unweighted averages are the average of the sum (over companies) of each source of finance in each year, divided by the sum of the growth of total assets. The Balanced samples for the four countries are as follows: India $=115$, Malaysia $=130$, Thailand $=98$, Korea $=95$, U.S.A. $=261$, U.K. $=752$

\begin{tabular}{|c|c|c|c|c|c|c|c|c|c|c|c|c|}
\hline & \multicolumn{2}{|l|}{ India } & \multicolumn{2}{|c|}{ Malaysia } & \multicolumn{2}{|c|}{ Thailand } & \multicolumn{2}{|l|}{ Korea* } & \multicolumn{2}{|l|}{ U.S.A. } & \multicolumn{2}{|l|}{ U.K. } \\
\hline & $\begin{array}{l}\text { Weight } \\
\text { ed }\end{array}$ & $\begin{array}{l}\text { Unweighte } \\
\text { d }\end{array}$ & $\begin{array}{l}\text { Weight } \\
\text { ed }\end{array}$ & $\begin{array}{l}\text { Unweighte } \\
\text { d }\end{array}$ & $\begin{array}{l}\text { Weight } \\
\text { ed }\end{array}$ & $\begin{array}{l}\text { Unweighte } \\
\text { d }\end{array}$ & $\begin{array}{l}\text { Weight } \\
\text { ed }\end{array}$ & $\begin{array}{l}\text { Unweighte } \\
\text { d }\end{array}$ & $\begin{array}{l}\text { Weight } \\
\text { ed }\end{array}$ & $\begin{array}{l}\text { Unweighte } \\
\text { d }\end{array}$ & Weighted & $\begin{array}{l}\text { Unweighte } \\
\text { d }\end{array}$ \\
\hline Retentions & 24.2 & 23.1 & 20.4 & 25.3 & 13.0 & 13.3 & 5.5 & 5.7 & 31.8 & 35.2 & 12.6 & 16.7 \\
\hline $\begin{array}{l}\text { External } \\
\text { finance }\end{array}$ & 75.8 & 76.9 & 79.6 & 74.7 & 87.0 & 86.7 & 94.5 & 94.3 & 68.2 & 64.8 & 87.3 & 83.2 \\
\hline Shares & 29.3 & 31.2 & 13.2 & 14.6 & 9.5 & 9.6 & 12.7 & 16.1 & 8.8 & 8.6 & 34.8 & 60.6 \\
\hline Other** & 1.7 & 2.5 & 8.3 & 9.1 & 6.3 & 6.3 & 2.0 & -2.3 & 0.7 & 1.9 & -5.3 & -13.5 \\
\hline Debt finance & 44.7 & 43.3 & 58.1 & 51.0 & 71.2 & 70.8 & 79.8 & 80.6 & 58.7 & 54.3 & 57.8 & 36.1 \\
\hline Long-term debt & 12.1 & 13.2 & 13.9 & 12.9 & 34.0 & 34.0 & 33.0 & 32.4 & 30.6 & 31.4 & 8.9 & 14.9 \\
\hline Short-term debt & 32.7 & 30.1 & 44.2 & 38.1 & 37.2 & 36.9 & 46.8 & 48.2 & 28.1 & 22.9 & 48.9 & 21.2 \\
\hline Trade credit & 8.3 & 8.3 & 7.2 & 6.4 & 6.2 & 6.4 & 12.5 & 13.1 & 9.9 & 10.9 & 27.6 & 33.0 \\
\hline
\end{tabular}

* Unweighted ratios for Korea are calculated over the 3 year period, 1994-96. Some unusually large ratios for 1993 were omitted from the overall average.

** Other includes revaluation reserves, minority interests, preferred shares and non-equity reserves. 


\section{Table 5}

\section{Balanced sample: Sources of financing of growth of Net Assets, 1992 - 1996}

Weighted averages are calculated as the sum (over companies) of each source of finance over the sample period, 1992-96, divide by the sum of the change in net assets over this period. Unweighted averages are the average of the sum (over companies) of each source of finance in each year, divided by the sum of the growth of net assets. Net assets are total assets less current liabilities. The Balanced samples for the four countries are as follows: India $=115$, Malaysia $=130$, Thailand $=98$, Korea $=95$, U.S.A. $=261$, U.K. $=752$.

\begin{tabular}{|c|c|c|c|c|c|c|c|c|c|c|c|c|}
\hline \multirow{2}{*}{$\begin{array}{l}\text { Growth of net } \\
\text { assets }\end{array}$} & \multicolumn{2}{|l|}{ India } & \multicolumn{2}{|c|}{ Malaysia } & \multicolumn{2}{|l|}{ Thailand } & \multicolumn{2}{|l|}{ Korea } & \multicolumn{2}{|l|}{ U.S.A. } & \multicolumn{2}{|l|}{ U.K. } \\
\hline & $\begin{array}{l}\text { Weight } \\
\text { ed }\end{array}$ & $\begin{array}{l}\text { Unweighte } \\
\text { d }\end{array}$ & $\begin{array}{l}\text { Weight } \\
\text { ed }\end{array}$ & $\begin{array}{l}\text { Unweighte } \\
\text { d }\end{array}$ & $\begin{array}{l}\text { Weight } \\
\text { ed }\end{array}$ & $\begin{array}{l}\text { Unweighte } \\
\text { d }\end{array}$ & $\begin{array}{l}\text { Weight } \\
\text { ed }\end{array}$ & $\begin{array}{l}\text { Unweighte } \\
\text { d }\end{array}$ & $\begin{array}{l}\text { Weight } \\
\text { ed }\end{array}$ & $\begin{array}{l}\text { Unweighte } \\
\text { d }\end{array}$ & $\begin{array}{l}\text { Weight } \\
\text { ed }\end{array}$ & $\begin{array}{l}\text { Unweighte } \\
\text { d }\end{array}$ \\
\hline Retentions & 36.0 & 34.8 & 36.6 & 39.6 & 20.7 & 20.3 & 10.3 & 15.1 & 44.2 & 45.3 & 24.8 & 28.5 \\
\hline External finance & 64.0 & 65.2 & 63.4 & 60.4 & 79.3 & 79.8 & 89.7 & 84.9 & 55.8 & 54.7 & 75.2 & 71.5 \\
\hline Shares & 43.5 & 43.4 & 23.6 & 23.5 & 15.2 & 15.3 & 24.0 & 20.9 & 12.3 & 10.6 & 68.1 & 75.8 \\
\hline Other* & 2.6 & 3.4 & 14.8 & 14.5 & 10.0 & 10.4 & 3.7 & 19.5 & 1.0 & 1.1 & -10.3 & -7.9 \\
\hline Long-term debt & 17.9 & 18.5 & 25.0 & 22.4 & 54.2 & 54.1 & 62.0 & 44.4 & 42.5 & 43.0 & 17.5 & 3.6 \\
\hline
\end{tabular}

- Other includes revaluation reserves, minority interests, preferred shares and non-equity reserves. 


\section{Table 6:}

Balanced sample: Unweighted average sources of financing of growth of net assets: 1992-1996

The balance samples for the four countries are: India $=115$, Malaysia $=130$, Thailand $=98$, Korea $=95$

\begin{tabular}{lllll}
\hline & India (\%) & Malaysia (\%) & Thailand (\%) & Korea (\%) \\
\hline Net asset growth & 37.2 & 32.9 & 39.7 & 20.6 \\
Retentions & $\mathbf{3 6 . 9}$ & $\mathbf{5 6 . 9}$ & $\mathbf{4 8 . 0}$ & $\mathbf{1 3 . 7}$ \\
External finance & $\mathbf{6 4 . 9}$ & $\mathbf{4 6 . 8}$ & $\mathbf{5 5 . 6}$ & $\mathbf{9 6 . 5}$ \\
Long term debt & 40.6 & 14.4 & 36.1 & 67.8 \\
Shares & 24.0 & 18.2 & 15.9 & 21.1 \\
Other & 0.3 & 14.2 & 3.6 & 7.6 \\
Statistical adjustment & -1.9 & -3.8 & -3.5 & -10.2 \\
\hline
\end{tabular}

Note: All cases where average annual rates of growth of net assets was less than one percent were rejected since low values of growth (the denominator) would lead to high values for the whole ratio. Internal and external finance were constrained to those between -100 per cent and +200 per cent (see Singh 1995, TP2). Internal and external finance were calculated as in Singh (1995), TP2, page 39. Note also that external finance of net assets by equity (new shares) was calculated directly as against the residual used in TP2.

The statistical adjustments in the table arise from the constraints placed on the financial ratios.

Source: World Scope database 
Table 7:

Balanced sample: Unweighted average sources of financing of growth of net assets: 1992-1996

The balance samples for the four countries are: India $=115$, Malaysia $=130$, Thailand $=98$, Korea $=95$

\begin{tabular}{lllll}
\hline & India (\%) & Malaysia (\%) & Thailand (\%) & Korea (\%) \\
\hline Retentions & $\mathbf{3 6 . 9}$ & $\mathbf{5 6 . 9}$ & $\mathbf{4 8 . 0}$ & $\mathbf{1 3 . 7}$ \\
External finance & $\mathbf{6 3 . 1}$ & $\mathbf{4 3 . 1}$ & $\mathbf{5 2 . 0}$ & $\mathbf{8 6 . 3}$ \\
Long term debt & 40.6 & 14.4 & 36.1 & 67.8 \\
Shares & 22.5 & 28.6 & 15.9 & 18.5 \\
Total & 100.0 & 100.0 & 100.0 & 100.0 \\
\hline
\end{tabular}

Note: This table was constructed using Singh (1995), TP2 residual method. Retentions and long-term debt were calculated directly and new shares were the residual sources of funds.

Source: World Scope database 


\begin{tabular}{|c|c|c|c|c|c|c|c|c|c|c|c|c|c|c|c|c|}
\hline & 1980 & 1981 & 1982 & 1983 & 1984 & 1985 & 1986 & 1987 & 1988 & 1989 & 1990 & 1991 & 1992 & 1993 & 1994 & 1995 \\
\hline \multicolumn{17}{|l|}{ Emerging Markets } \\
\hline Argentina & 3.4 & 1.7 & 1.3 & 0.7 & 1.2 & 1.5 & 3.4 & 2.4 & 1.1 & 0.5 & 5.6 & 1.4 & 1.7 & 2.5 & 1.9 & 0.6 \\
\hline Brazil & 4.5 & 1.4 & 3 & 1.4 & 1.6 & 1.2 & 2.8 & 2.3 & 1.2 & 1.5 & 4.8 & 1.9 & 2.1 & 0.8 & 1.4 & 1.4 \\
\hline Chile & na & na & na & na & 3.9 & 14.6 & 6.1 & 17.4 & 8.1 & 2.9 & 1.9 & 0.7 & 1.6 & 1.8 & 0.1 & 1.9 \\
\hline China & & & & & & & & na & na & na & na & 0.4 & 0.1 & 0.1 & 0 & na \\
\hline Colombia & 2.6 & 6.6 & 7.5 & 24.5 & 10.5 & 15.5 & 9.6 & 8.4 & 7.1 & 5.1 & 4.1 & 1.7 & 1.9 & 2.2 & 3.9 & 1.1 \\
\hline Hungary & &.. & & & &. .0 & & & &.. & na & 0.1 & 50 & 12.4 & 24.3 & 42.9 \\
\hline India & 0 & 0.2 & 0.5 & 0.3 & 0.5 & 0.2 & 0.4 & 0.1 & 0.3 & 0.1 & 0.2 & 0.2 & 0.6 & 0.4 & 0.5 & na \\
\hline Indonesia & 89.6 & 80.6 & 21.3 & 38.9 & 0.3 & 0 & 0.4 & 0 & 10.4 & 52.3 & 38.6 & 7.3 & 8.9 & 7.1 & 10.3 & 5.9 \\
\hline Jamaica & 0 & 0 & 1.9 & 0 & 0 & 0 & 2.1 & 0.2 & 0.7 & 0.6 & 0.2 & 0.1 & 1.4 & 3.2 & 0.8 & 0.2 \\
\hline Jordan & 9.9 & 9.2 & 9.1 & 6.3 & 0.7 & 1.1 & 1.1 & 3.1 & 0.8 & 1.8 & 0.8 & 1.2 & 2.4 & 6.7 & 14.4 & 10.2 \\
\hline Kenya & & & & & na & na & 1.6 & 0.4 & 2.7 & 3 & 2.9 & 1.4 & 2.4 & 0.1 & 1.6 & 0 \\
\hline Malaysia & 0.5 & 2.6 & 1.9 & 2.2 & 4.4 & 1.5 & 1.1 & 1.9 & 1.6 & 1.5 & 6.5 & 1.7 & 3.3 & 0.6 & 1.4 & 1.6 \\
\hline Mauritius & & .. &... & .. & .. & & . & &.. & .. & 4.2 & 2.2 & 25.8 & 1 & 8.9 & 7.2 \\
\hline Mexico & 0.2 & 0.8 & $\ddot{0}$ & $\ddot{0}$ & 0.1 & 0.7 & 0.3 & $\ddot{5.8}$ & 0.5 & $\ddot{0}$ & 0.6 & 3.4 & 1.2 & 1.2 & 1.4 & 0 \\
\hline Pakistan & 7 & 15.9 & 5.8 & 10.5 & 11.5 & 4 & 8.7 & 5.5 & 8.5 & 11 & 14.5 & 11.4 & 6.2 & 10.7 & 8.1 & na \\
\hline Peru & 0 & 0.2 & 0 & 0 & 0.1 & 0.5 & 3.6 & 0.7 & 0 & 0 & 0 & 0 & 0 & 0 & 0 & 0 \\
\hline Philippines & 5.5 & 21.3 & 1.4 & 1.1 & 2 & 1 & 0.4 & 2.6 & 2.2 & 1.2 & 4.6 & 3.8 & 0.9 & 1 & 2.7 & 2.5 \\
\hline Portugal & na & na & na & na & na & na & 21.8 & 9.8 & 19.8 & 12.8 & 29.6 & 22.2 & 33.5 & 20.7 & 12.4 & 23.3 \\
\hline Sri Lanka & na & na & na & na & na & na & na & 0.8 & 2.5 & 1.5 & 1.4 & 1.1 & 4.9 & 4.2 & 7.8 & 3.5 \\
\hline Thailand & 8.4 & 6 & 7.8 & 8.4 & 21.9 & 9.7 & 3 & 21.7 & 4.9 & 20.1 & 21.9 & 17.6 & 15.4 & 1 & 2.5 & 1.8 \\
\hline Tunisia & na & na & na & na & na & na & 42.6 & 23.5 & 25.7 & 32.2 & 77.8 & 58 & 64.6 & 44.9 & 16.6 & 22.8 \\
\hline Turkey & 0 & 0 & 5.8 & 16.1 & 18.5 & 19.7 & 16.2 & 6.8 & 23.2 & 6.8 & 8.3 & 7 & 7.9 & 2.4 & 6.4 & 5.4 \\
\hline Venezuela & 12.9 & 5.1 & 6.5 & 9.1 & na & 12.8 & 18.5 & 9.8 & 43.4 & 55 & 6.1 & 11 & 10.4 & 10.1 & 17.2 & 18.3 \\
\hline \multicolumn{17}{|l|}{ Asian Tigers } \\
\hline Hong Kong & na & na & na & na & na & na & na & na & na & na & 2.9 & 3.9 & 7.6 & 2.6 & 2 & 1.6 \\
\hline Korea & 151.9 & 120.8 & 140.3 & 264 & 153.7 & 81.4 & 87.6 & 92.7 & 134.4 & 180.2 & 54.3 & 42.9 & 25.9 & 19.2 & 27.2 & 43.9 \\
\hline Taiwan & 7.7 & 3.7 & 6.5 & 2.4 & 3.9 & 2.5 & 2.3 & 2.1 & 0.9 & 0.6 & 1.2 & 1.6 & 2 & 1.3 & 1.3 & 1.7 \\
\hline Singapore & 0.9 & 0.8 & 0.8 & 2.2 & 2.4 & 1 & 0.1 & 2.1 & 1.7 & 1 & 2.4 & 0.8 & 1.4 & 2.7 & 1 & 0.3 \\
\hline \multicolumn{17}{|c|}{ G4 Industrial Countries } \\
\hline Germany & 5.3 & 3.9 & 3.5 & 3.5 & 2.8 & 2.1 & 2.9 & 3.1 & 1.7 & 2.8 & 4.9 & 2 & 3.2 & 2.5 & 3.8 & 2.9 \\
\hline Japan & 1.8 & 2.6 & 2.1 & 1.3 & 1.6 & 1.1 & 0.8 & 1.5 & 1.7 & 2.5 & 1.5 & 0.3 & 0.2 & 0.4 & 0.4 & 0.3 \\
\hline U.K. & 1.1 & 2.1 & 1 & 1.6 & 0.9 & 1.8 & 2.6 & 3.8 & 1.3 & 1.4 & 0.8 & 1.9 & 1.1 & 2.1 & 1.8 & 0.8 \\
\hline U.S.A. & 1.6 & 1.9 & 2 & 2.7 & 1.2 & 1.5 & 2.3 & 2.1 & 1.4 & 0.9 & 1.2 & 1.7 & 1.9 & 2.3 & 1.3 & 1.1 \\
\hline
\end{tabular}

Source: Aylward and Glen

(2002). 


\section{References}

Aylward, A. and J. Glen (2002). "Primary Securities Markets: Cross Country Findings", International Finance Corporation Discussion Paper No. 39. Washington, D.C.: The World Bank.

Balasubramanian, N. (1993). Corporate Financial Policies and Shareholder Returns: the Indian Experience. New Delhi: Himalaya Publishing House.

Berle, A. and G. Means (1933). The Modern Corporation and Private Capital. New York: Macmillan.

Bhide, A. (1994). "The hidden cost of stock market liquidity". Journal of Financial Economics, 34, pp. 31-51.

Brealey, Richard A. and Steward C. Myers (eds.) (1999), Principles of Corporate Finance, $6^{\text {th }}$ edition McGraw-Hill, U.S.A.

Camdessus, M. (1998). Speech to Transparency International reported in the IMF Survey, 9 February, 1999.

Chang, H.-J. (2000). "The hazard of moral hazard - untangling the Asian Crisis", World Development, Vol. 28, No. 4.

Cobham, David and Ramesh Subramaniam (1998), "Corporate Finance in Developing Countries: New Evidence for India", World Development.

El-Erian, M. A. and Kumar, M. S. (1994) Emerging Equity Markets in Middle Eastern Countries. In World Bank Conference on Stock Markets, Corporate Finance and Economic Growth, The World Bank, Washington, DC, February 16-17. 
Frankel, J. A. (1998). "The Asian Model, the Miracle, the Crisis and the Fund". Paper delivered at the U.S. International Trade Commission, April 16, 1998.

Glen, J., K. Lee and Singh, A. (2000), Competition, Corporate Governance and Financing of Corporate Growth in Emerging Markets, Cambridge Discussion Paper in Accounting and Finance No. AF46, Department of Applied Economics, University of Cambridge.

Graham, Benjamin and David Dodd (1934). Securities Analysis. New York: McGraw-Hill.

Greenspan, A. (1998). Testimony before the Committee on Banking and Financial Services, U.S. House of Representatives, January 30, 1998.

Gugler, K., D. Mueller and B. B. Yurtoglu (2002). "The Impact of Corporate Governance on Investment Returns in Developed and Developing Countries", University of Vienna manuscript.

Hall, R. E. (2001) Struggling to Understand the Stock Market. The American Economic Review, Papers and Proceedings.

Hughes, A. (1991). "Mergers and Economic Performance in the U.K.: A Survey of the Empirical Evidence 1950-1990", in J. Fairburn and J. A. Kay (Eds.), Mergers and Merger Policy. Oxford, second edition.

Harris, M. and A. Raviv (1991). The Theory of Capital Structure. Journal of Finance . March, 46(1), 297-355.

IMF (1997). World Economic Outlook: Interim Assessment. Washington, D.C.: IMF.

IMF (1998). World Economic Outlook and International Markets. Washington, D.C.: IMF.

India Today. June 16, 1997. 
Johnson, S., P. Boone, A. Breach and E. Friedman (2000). "Corporate Governance in the Asian Financial Crisis", Journal of Financial Economics, Vol.58, pp.141-86.

Keynes, J. M. (1936). The General Theory of Employment, Interest and Money. New York: Harcourt, Brace and Company.

La Porta, R., F. Lopez-de-Silanes, A. Shleifer and R. W. Vishny, (1997). "Legal Determinants of External Finance", Journal of Finance, 54, 471-517.

La Porta, R., F. Lopez-de-Silanes, A. Shleifer and R. W. Vishny (1998). "Law and Finance", Journal of Political Economy, 106, 1113-55.

La Porta, R., F. Lopez-de-Silanes, A. Shleifer and R. W. Vishny (1999). "Investor Protection: Origins, Consequences, Reform", Harvard University, manuscript.

La Porta, R., F. Lopez-de-Silanes, A. Shleifer and R. W. Vishny (2000). "Agency Problems and Dividend Policies Around the World", Journal of Finance Mayya, M. R. (1995). Reflections on the Changing Scenario of the Indian Stock Markets. Bombay: A. D. Schroff Memorial Trust.

Modigliani, F. and M. H. Miller (1958). "The Cost of Capital, Corporate Finance and the Theory of Investment". American Economic Review. June 48 (4), 261-297.

Mullins, J. (1993) Emerging Equity Markets in the Global Economy. FRBNY Quarterly Review (Summer) 54-83.

Myers, S. C. (2001) Capital Structure. The Journal of Economic Perspectives. 15 (2), 81102.

Myers, S. and N. Majluf, (1984) "Corporate Financing and Investment Decisions When Firms Have Information that Investors Do Not Have", Journal of Financial Economics, 13, 187-221. 
Pal, P. (2001). "Stock Market Development and its Impact on the Financing Pattern of the Indian Corporate Sector", NSE Research Initiative, Working Paper No. 004. Mumbai, India.

Peacock, A. and G. Bannock (1991). Corporate take-overs and the public interest. Aberdeen: Aberdeen University Press for the David Hume Institute.

Phelps, E. S. (1999). "The Global Crisis of Corporatism", The Wall Street Journal, 25 March, 1999.

Porter, Michael E. (1992). "Capital disadvantage: America's falling capital investment system". Harvard Business Review, September-October, pp. 65-82.

Prais, S. J. (1976) The Evolution of giant Firms in Britain. Cambridge University Press, Cambridge.

Reserve Bank of India (1995). Report on Currency and Finance 1994-1995. Bombay: RBI.

Sakakibara, E. (2001). "The East Asian Crisis - Two Years Later". Annual World Bank Conference on Development Economics 2000, pp.243-55. The International Bank Reconstruction and Development/The World Bank.

Samuel, Cherian (1996), The Stock Market as a Source of Finance: A Comparison of U.S. and Indian Firms. World Bank Policy Research Working Paper 1592.

Shiller, R. J. (2000) Irrational Exuberance. Princeton University Press, Princeton, New Jersey.

Shleifer, A. and L. Summers (1988). "Breach of trust in hostile take-overs", in Alan Auerbach (ed.) Corporate take-overs: Causes and consequences. Chicago: University of Chicago. 
Shleifer, A. and R. Vishny. (1997) A Survey of Corporate Governance. Journal of Finance, 52, 737-783.

Singh, A. (1971). Take-overs, Their Relevance to the Stock Market and the Theory of the Firm. Cambridge: Cambridge University Press.

Singh, A. (1975). "Take-overs, Economic Natural Selection and the Theory of the Firm". Economic Journal, September.

Singh, A. (1992). "Corporate Take-overs", in J. Eatwell, M. Milgate and P. Newman (Eds.), The New Palgrave Dictionary of Money and Finance. London: Macmillan, pp. 4806.

Singh, A. (1995) Corporate Financial Patterns in Industrializing Economies: A Comparative International Study. IFC Technical Paper 2. Washington, DC: IFC.

Singh, A. (1997) Financial Liberalisation, Stock Markets and Economic Development”, Economic Journal, 107, 771-782.

Singh, A. (1998a). "Liberalisation, the stock market and the market for corporate control: a bridge too far for the Indian economy?" in I. J. Ahluwalia and I. M. D. Little (Eds.) India's Economic Reforms and Development: Essays for Manmohan Singh. Oxford.

Singh, A. (1998b). "Financial crisis in East Asia: The end of the Asian model?". Issues in Development, Discussion Paper 24. Geneva: ILO.

Singh, A. (1999). "Should Africa promote stock market capitalism?", Journal of International Development. 11: 343-365.

Singh, A. (2000). "The Anglo-Saxon market for corporate control: The financial system and international competitiveness", in Candice Howes and Ajit Singh (Eds.) Competitiveness Matters: Industry and economic performance in the U.S.. Ann Arbour: University of Michigan Press. 
Singh, A., and J. Hamid. (1992). Corporate Financial Structures in Developing Countries. Technical Paper 1, IFC, Washington DC.

Singh, A., and B. Weisse (1998). "Emerging Stock Markets, Portfolio Capital Flows and Long-Term Economic Growth: Micro and Macro Perspectives.” World Development, 26 (4), 607-622.

Singh, A., and B. Weisse (1999). "The Asian Model: A crisis foretold?", International Social Science Journal, No. 160, pp.203-215.

Singh, A., A. Singh and B. Weisse (2000). Information Technology, Venture Capital and the Stock Market, Cambridge Discussion Paper in Accounting and Finance No. AF47, Department of Applied Economics, University of Cambridge.

Singh, A., A. Singh and B. Weisse (2002). Corporate Governance, Competition, the New International Financial Architecture and Large Corporations in Emerging Markets, forthcoming as a Cambridge Discussion Paper, Centre for Business Research, University of Cambridge.

Stein, J. C. (1989). "Efficient stock markets, inefficient firms: A model of myopic corporate behaviour". Quarterly Journal of Economics, November.

Stiglitz, J. (1999). "Reforming the Global Financial Architecture: Lessons form Recent Crises", Journal of Finance, 54(5): 1508-22.

Summers, L. H. (2000). "International Financial Crises: Causes, Prevention and Cures", American Economics Review Papers and Proceedings, 90(2), pp. 1-16.

Tirole, J. (1991) Privatisation in Eastern Europe: Incentives and the Economics of transition. In NBER Macroeconomics Manual 1991, ed. Blanchard, O.J. and S.S. Fischer. The MIT Press, Cambridge, MA. 
Tobin, J. (1984). "On the efficiency of the financial system". Lloyds Bank Review, 1-15 July.

U.S. Council for Economic Advisers (1998). Economic Report of the President. Washington, D.C.: U.S. Government Printing Office.

U.S. Council for Economic Advisers (1999). Economic Report of the President. Washington, D.C.: U.S. Government Printing Office.

Whittington, G., V. Saporta, and A. Singh (1997). The Effect of Hyper-Inflation on Accounting Ratios- Financing Corporate Growth in Industrial Economies. IFC Technical Paper 3. World Bank, Washington D.C.

Wolfensohn, J. (2000), quoted on Worldbank.org in "Remarks by Mark Baird, Transparency and Corporate Governance", April 25, 2000.

World Scope Databank. 